\title{
DIGITAL NATIVES OR NOT? HOW DO ROMANIAN ADOLESCENTS CROSS THE BOUNDARIES OF INTERNET COMMON USE
}

\author{
BIANCA BALEA 1
}

\begin{abstract}
The present paper challenges the dominance of the digital natives' agenda and turns its attention to the social context in which Internet usage among adolescents occurs. Findings indicate that even when young people are using the Internet with the same frequency, i.e. every day, the differences among them remain significant. Therefore, it can be argued that considering an entire cohort to be similar in terms of Internet use only due its age is a misconception. The way children make use of the Internet and the gratifications they gain after using it depend, as van Dijk (2005) showed, on the quality of access, on the level of skills, and on the personal (e.g. Experience, self-efficacy, confidence) and positional resources (e.g. Age, gender, socio-economic status). Questioning the main determinants that lead to the most advanced way to make use of the Internet, the logistic analysis shows that, in order for a Romanian adolescent to turn into an experienced user once he or she embedded the Internet in his or her everyday life, is a matter of skills, experience, and time online, and is less a matter of socioeconomic background. However, we have to keep in mind the previous path analysis' findings, which emphasize that online experience, time spent online, self-efficacy, and digital skills are all determined, through direct or indirect effects, by demographic variables (i.e. age, gender and socio-economic status), even when age is held constant (Fizesan [Balea], 2012).
\end{abstract}

Keywords: digital natives, digital engagement, ladder of opportunities, digital inequalities

\section{Introduction}

Understanding what children do online, what techniques they use in order to embed the Internet in their everyday life could offer valuable insights regarding the benefits/gratifications gained from the use of the Internet or other communication technologies. Unfortunately, more often than not, studying

${ }^{1}$ Faculty of Sociology and Social Work, Babeș-Bolyai University Cluj-Napoca, e-mail: bianca.balea85@gmail.com. 
the digital differences among children was a matter of focusing on the relations between age, gender, socio-economic status (SES), and other demographic variables with the way children and young people access and use the Internet. Recently, scholars turned their attention to other factors which can increase silent inequalities within Internet users (DiMaggio et al., 2004, Hargittai, 2010). Digital literacy has received a lot of attention lately in relation to opportunities that children and adults take up online, making Internet skills a possible contributor to social inequalities (Livingstone and Helsper, 2007, 2010; Van Deursen, 2010; Helsper and Enyon, 2009). Witte and Mannon (2009) consider digital literacy as a particular skill set and knowledge base that might be used to maintain class advantage while the lack of it may translate into class disadvantage. Numerous studies on children and adolescents' Internet usage have shown, indeed, that those who are more skilled undertake a broader range of activities and are able to participate to a greater extent in digital practices.

EU Kids Online II findings have revealed that the number of online activities young people undertake highly correlate with their level of digital skills and their confidence in own use (Lobe et al., 2011). According to the last, children climb on a ladder of opportunities, beginning with information seeking, progressing through games and communication, taking on more interactive forms of communication and culminating in creative and civic activities. Only a quarter of European children reach the last, most advanced and creative step according to the model proposed by Hasebrink et al. (2011). Considering all of the above, it is a legitimate reason to question the popular assumption that children and young people are digital savvy (Livingstone and Helsper, 2010; Helsper and Enyon, 2009), and to search for determinants of differentiated use among them.

\section{Literature review}

Digital natives is one of the most popular narratives that address the way the younger generation makes use of the new forms of information and communication technologies. This approach claims that these young people, who have grown up with ICT, have sophisticated technology skills and a whole new set of cognitive capacities (Kennedy et al., 2008). However, recent research shows that this idea has gained widespread popularity on the basis of claims rather than evidence. On this basis, several academics have challenged the dominance of the digital native model and examined the influence of the social context in which skills develop (Facer and Furlong, 2001).

The mainstream discourse of digital native narratives often omits that breadth of use, experience, self-efficacy and education can generate differences in the way children and adolescents make use of the Internet. Mainly, this view 
assumes that children use online information effortlessly, due to the fact that they have grown with it. Therefore, they feel comfortable and confident in online environments "seemingly never in need of an instruction manual" (Lorenzo et al., 2006; Green and Hannon, 2007; Kennedy et al., 2008).

The first researcher who coined the term digital natives was Prensky in 2001, who focused to the new generation which has grown up with these new technologies and spent their entire lives "surrounded by and using" all kinds of tools of the digital age, i.e. computers, video games, cell phones. Today's young adults "think and process information fundamentally differently from their predecessors", due to these circumstances. Furthermore, those who are born into this new culture learn the language of the information society easily like their native language which help them not only to consume the information received via various devices, but also to create and re-create it (Lorenzo et al., 2006). Consequently, those who were not born into the digital world but have adopted most aspects of the new technology are named as digital immigrants. Moreover, according to the same viewpoint, older people are always one step behind and unable to reach the natural adopting of new technology that is specific for those who have grown with them (Jones and Healing, 2010). However, agreement is hard to reach with regard to which generation is digitally native. Within Prensky's original work, children born after 1980 are digitally native, an idea supported by other scholars like Obeliner and Obliner who position the start of this new generation, named Millenials, in or after 1982 (Jones and Healing, 2010). However, according to the recent literature this category seems to have shifted. The rise of web 2.0 applications created a second generation of digital natives, placing the distinction line in 1990 (currently 26 or younger), which means that young adults born between 1983 and 1990 are the first generation of digital natives (Helsper and Enyon, 2009). Regardless of the year in which they were born, the first generation and the second generation of digital natives are assumed to have broadly universal experiences, but also a sophisticated knowledge and understanding of information and communication technologies (Kennedy et al., 2008).

In spite of this claim made for the existence of a generation of digital natives (also named the Net generation, the Google generation, or the millennials), the findings of the most recent studies (Bennett et al., 2008; Kenedy et al., 2010; Helsper and Enyon, 2009; Bennett and Maton, 2010) argue against its homogenous view on this entire generation (i.e. Children and young adults) by emphasizing that generalizing the ways in which digital natives cope with these new technologies is a misconception since it fails to recognize the variations in young peoples' Internet usage. Furthermore, these variations are caused both by demographic variables like age, gender, socioeconomic status, and ethnicity, and cognitive factors 
(Bennett et al. 2008). Moreover, same studies suggest that the research of the relationship between children and new media should go beyond basic dichotomies evident in digital natives debate to develop a more comprehensive understanding of children's online behaviour. Drawing on this academic context, several scholars have challenged the dominance of the digital natives agenda and turned their attention to the social context in which skills develop (Bennet et al., 2008; Kennedy et al., 2009; Helsper and Enyon, 2009; Bennet and Maton, 2010). It was not long until it became obvious that children's Internet access and use are not equal and easy for all of them (Bennett et al., 2008), resulting in significant differences in how effectively and why young people use these technologies (Helsper and Enyon, 2009).

The research evidence indicates that, indeed, many teenagers correspond to the label digital natives. They adapt quickly to the new technology and use this technology to undertake a significant amount of information and activities. However, at the same time, it appears that many young people do not have the levels of access or technology skills predicted by advocates of the digital native idea (Bennett et al., 2008). On these lines, drawing on a questionnaire of 855 children with low computer skills and group interviews with 46 young people with the same profile, Facer and Furlong (2001) reported accessing computer difficulties, a lack of relevance of computer technology to these children's daily lives, and the potential of formal educational environments to exacerbate inequalities in access and anxieties around computer use. Moreover, as the same study argues, these children, which are unable to use and access new technologies, will be marginalized from key aspects of economic and social activity (Facer and Furlong, 2001). Likewise, several other studies reveal the same conclusions. Bennett and Manton (2010), which have focused their research on the extent of young people's access and use of technology, revealed that different histories of access and use, which result in different opportunities, are the core assumptions which describe children's Internet use. Jones et al. (2010) conducted a two year study, which started in 2008, in five universities in England investigating young adults' online behaviour. Their results illustrate significant variation of Internet use, within and between age groups. Even if most of the students engage frequently in a wide range of activities, for some, the participation and generational homogeneity predicted by digital native narratives is not supported (Jones et al. 2010). Kennedy et al. (2008) have also focused their attention on student population with regard to technology and a potential digital divide between them. Their study highlights the lack of homogeneity in the level of digital skills students possess.

On the same lines, the research conducted by Helsper and Enyon (2009) reports some intriguing results. On the one hand, their findings support to a certain degree the digital natives narratives. Accordingly, a large number of young people 
are using the Internet, are more likely to live in a media rich homes, to be confident in their own skills and to engage in online learning activities. However, the same findings support a continuum engagement instead of a dichotomous divide between those who have grown up with these new technologies and those who did not. As other research emphasizes, Helsper and Enyon (2009) demonstrate that there are significant disparities among young people in terms of their preferences, skills and use of new technologies.

Hargittai (2010) also conducted a study that is worth mentioning in order to complete the final picture of the issue addressed in this section. In order to test the assumption that young people are universally savvy with the information and communication technologies, Hargittai (2010) has conducted an original study in the U.S that reports significant differences in young adults' Internet skills and activities even when controlling for Internet access and experiences. Moreover, according to the same work, higher levels of parental education, being a male, and being white or Asian American are significant predictors of high levels of Internet skills, which in turn positively relate with types of uses. The major contribution of this study is that its results emphasize that socioeconomic status remains a significant predictor of how young people are incorporating the Internet into their everyday lives, even when controlling for basic Internet access. Accordingly, those from more privileged backgrounds are using the Internet in more "informed way for a large number of activities" (Hargittai, 2010, p. 19). Moreover, Hargittai (2010) argues that even among this "highly wired group" (p. 19) systematic variation in online Internet skills exists.

Along with these studies, in a previous work (Balea, 2012) we tested for differences in digital engagement among Romanian 11-16 year-olds who incorporate the Internet in their everyday life. The results were very similar with the ones described above. A path analysis was used in order to count for predictors of different levels of digital skills, self-efficacy and digital engagement among Romanian adolescents. Among the independent variables that measured children's SES background (child's age, child's gender, parent's educational level and parent's age), four intermediate variables were also implied in the model: online experience, autonomy of use, parental support and peer support. Most important results showed that older children are receiving more support from their friends, lees from their families, have more experience, and they are more digitally engaged. Boys are more experienced than girls, use the Internet from various locations and are more skilful. Moreover, children from privileged backgrounds are receiving more support from their families, have greater experience and autonomy of use and possess more skills. Nevertheless, children whose parents are younger, and are receiving more support from them are more experienced, skilled, and are engaging in various activities than children 
whose parents are older. In spite that this analysis considers only children who are using the Internet every day, the final path model emphasizes significant digital differences among Romanian adolescents when it comes to quality of access, usage and taking up online opportunities. The results obtained from conducting this path analysis emphasize that even those adolescents that use the Internet every day exhibit various ways of engaging with the Internet. For that reason, those observed paths reinforce other findings that reject the ordinary notion of digital natives and highlight the complexity of adolescents' Internet experience (Bennett et al., 2008; Kenedy et al., 2009; Helsper and Enyon, 2009; Bennett and Maton, 2010).

Unfortunately, the path analysis does not provide any information about the types of activities that adolescents take up online. Helsper and Enyon (2009), and, also, Hargittai (2010) stress about the importance of knowing what kinds of activities children are most likely to conduct when access the Internet, this information being a significant indicator of the intensity of the digital engagement. In order to understand this diversity, there are some studies that go beyond the number of online activities when trying to explain how children are digital engaged, by considering the types of online opportunities taken up, some more capital-enhancing than others.

On these lines, Livingstone and Helsper (2007) propose a gradation in digital inclusion among children: certain basic activities tend be done first, and by most children, while more creative or participatory activities come later and are undertaken by fewer children. This hypothesis named the ladder of opportunities was tested on EUKO II dataset by Lobe et al. (2011) and proposes five different stages of engagement, whereas the first one is reached by all children that are using the Internet and is composed by most common activities like use of Internet for schoolwork and playing games on your own against the computer. The last stage consists of the most difficult activities that require experience and skills, like visiting chat rooms, using file sharing sites, creating characters, spending time in a virtual world or writing a blog or a diary. This stage is regularly reached by those who use 13 or more online activities, meaning less than a quarter of European children (Lobe et. al, 2011). One of the most notable inferences of this theory refers at the lack of accuracy that the number of online activities offers when studying both digital engagement, and the benefits that a child undertake from its own Internet use. Accordingly, there are children or adolescents that undertake a broader range of online activities, but they never reach the last stage which is the most creative, advanced and gainful way to make use of the Internet. Therefore, the number of online activities is significant since, as the path analysis showed (Fizesan [Balea], 2012), is related to confidence, skills, amount of use, but is not sufficient in order to state if a child is digital engaged or not. 
For that reason, we need to offer a glance over those adolescents that reach the final step, the most creative and advanced one and to investigate what are the main factors that determine an adolescent to cross the boundaries of the common use. In order to accomplish such an aim, firstly is essential to understand how Romanian children climb on this "ladder of opportunities". Thus, the "ladder of opportunities" hypothesis was tested on Romanian EUKO II dataset, which includes all children 9-16 year-olds regardless of their frequency of Internet use $(\mathrm{N}=1,041)$.

Table 1 shows that the hierarchy of activities hypothesis is supported for Romanian children too, even though there are some differences compared to children across all 25 countries surveyed. Over $80 \%$ of Romanian children use the Internet for school work or for playing online against the computer or themselves while fewer (less than $20 \%$ ) post photos, videos or music to share it with others, create a character, pet or avatar or visit a chat room, and even fewer (less than 10\%) spend time in a virtual world, write a blog or online diary or use file sharing sites. In what follows all the five stages will be presented with reference to the findings on children across all countries surveyed.

Stage 1: this stage is represented by most popular activities that are, also, practiced by most of people who only engage in 1-2 activities. 9\% of Romanian young people practice less than two activities, predominantly using the Internet for schoolwork and using the computer for playing video games.

Stage 2: watching online video clips and using instant messages are the next popular activities, which are undertaken by almost one third of those who engage in 3-5 activities. 23\% of Romanian children conduct up to five of the activities listed, compared with $14 \%$ of the overall sample.

Stage 3: About one in three Romanian children (39\%) and three out of four European children take up to nine of the activities. This stage represents the use of the Internet interactively for communication (social networking, instant messaging, and email) and reading/watching the news.

Stage 4: One in five Romanian adolescents expands his activities to 10 or more opportunities, and is likely to engage in reading/watching news on the Internet, using a webcam or posting messages to others. These activities already include some conduct-related practices where young people become active contributors to the online environments. Across Europe, over half of 9-16 year old Internet users reach this point, although only one third of 9-10 year-olds and less than half of 11-12 year-olds do so (Livingstone et al., 2011).

Stage 5: these activities are regularly practiced by those who are able to use 13 or more online activities. A quarter of children across all countries reaches this last, most advanced, and creative step while only one in ten Romanian children undertakes more than 13 activities and more than a half of them engage in activities 
like visiting chat rooms, using filesharing sites, creating characters, spending time in a virtual world or writing a blog or a diary, which are in general practiced only by a small percentage of the overall population. These children, from the last stage, will represent the focus in the following analyses.

Table 1.

"Ladder of opportunities": type of opportunities taken up by Romanian children by age

\begin{tabular}{|c|c|c|c|c|c|c|c|}
\hline & & $\begin{array}{r}\text { Group } \\
\text { op }\end{array}$ & $\begin{array}{l}\text { acco } \\
\text { ortu }\end{array}$ & $\begin{array}{l}\text { ding } \\
\text { ities }\end{array}$ & $\begin{array}{l}\text { to num } \\
\text { taken } u\end{array}$ & $\begin{array}{l}\text { ber of } \\
\text { up }\end{array}$ & \\
\hline & $\%$ of people in each group & $0-2$ & $3-5$ & $6-9$ & $10-12$ & $13-17$ & Total \\
\hline & Used the Internet for school work & 60 & 85 & 93 & 96 & 100 & 87 \\
\hline solage 1 & Played games on your own & 58 & 77 & 78 & 86 & 96 & 83 \\
\hline Stage 2 & $\begin{array}{l}\text { Watched video clips } \\
\text { (e.g. on YouTube) }\end{array}$ & 15 & 65 & 95 & 97 & 98 & 77 \\
\hline & Used instant messaging & 20 & 79 & 97 & 98 & 100 & 82 \\
\hline & Sent/received email & 6 & 41 & 76 & 91 & 94 & 60 \\
\hline & Downloaded music or films & 6 & 27 & 75 & 93 & 100 & 57 \\
\hline Stage 3 & $\begin{array}{l}\text { Played games with other people } \\
\text { on the Internet }\end{array}$ & 19 & 41 & 64 & 87 & 94 & 57 \\
\hline & Visited a social networking profile & 1 & 18 & 70 & 89 & 98 & 51 \\
\hline & Used a webcam & 5 & 30 & 57 & 78 & 92 & 48 \\
\hline Stage 4 & $\begin{array}{l}\text { Read/watched the news on the } \\
\text { Internet }\end{array}$ & 2 & 11 & 36 & 75 & 75 & 33 \\
\hline & $\begin{array}{l}\text { Put (or posted) a message on a } \\
\text { website }\end{array}$ & 0 & 6 & 26 & 71 & 98 & 28 \\
\hline & $\begin{array}{l}\text { Put (or posted) photos, videos or } \\
\text { music to share with others }\end{array}$ & 0 & 3 & 20 & 54 & 90 & 22 \\
\hline & Created a character, pet or avatar & 1 & 6 & 17 & 36 & 70 & 18 \\
\hline Stage 5 & Visited a chat room & 1 & 1 & 12 & 43 & 74 & 15 \\
\hline & Spent time in a virtual world & 0 & 1 & 4 & 24 & 61 & 9 \\
\hline & Written a blog or online diary & 0 & 1 & 2 & 29 & 63 & 8 \\
\hline & Used file sharing sites & 0 & 0 & 1 & 11 & 61 & 5 \\
\hline
\end{tabular}

Source: Table adapted from Haserbrink et al., 2011. EU Kids Online dataset, author's computations. Base: All children 9+ in Romania ( $\mathrm{N}=1041)$. 
In sum, as in the case of children across all 25 countries, climbing on this ladder of opportunities is a matter of age, as most of the youngest children do not reach the final step. The majority of them lie between the first and second stage, using the Internet mostly for school work and playing online games. In total, only $9 \%$ of Romanian children engage in at least 13 activities, out of which $93 \%$ are 11 and 16 year-olds. However, being older is not a guarantee for an adolescent that he or she will make use of the Internet in a gainful way. Simple linear regressions were used to test for the theory that as children grow and use the Internet every day, the age is less and less relevant in predicting the range of activities undertaken, especially for girls. Accordingly, for the overall sample (All children, $9+, N=1,041)$ the age variation $\left(R^{2}=0.178\right.$, Male $R^{2}=0.22$, Female $\left.R^{2}=0.14\right)$ explains about $18 \%$ in the variation of the number of online activities, for 11-16 year-olds sample $(\mathrm{N}=771)$ it explains less than $10 \%\left(\mathrm{R}^{2}=0.09\right.$, Male $\mathrm{R}^{2}=0.13$, Female $\mathrm{R}^{2}=0.05$ ), whereas in the case of the girls is almost insignificant. Finally, in the case of 11-16 year-olds that make use of the Internet every day $(\mathrm{N}=595)$ the age variation explains about $7 \%$ of the total variation in the number of online activities $\left(R^{2}=0.07\right)$, where for male children $R^{2}=0.12$, female $\left.R^{2}=0.03\right)$, which statistically is insignificant. Therefore, even if studies show (Barbovschi and Fizesan [Balea], 2013) that the gender gap seems to diminish, if we look at the entire cohort, there are important gender differences between adolescents, with boys more likely to engage in a creative use than girls, regardless of their age. Thus, there is reason to question the main predictors for an adolescent to make use of the Internet in a creative and capital-enhancing way.

\section{Sample and method}

In order to explain which factors influence the odds ratio for a young person to be involved in the most creative and advanced step when access the Internet, a logistic regression was conducted on 11-16 year-olds from Romania which use the Internet on daily bases (EU Kids Online dataset) since 11-16 year-olds are considered, according to previous findings (Haserbrink et al., 2011, Balea, 2012), to be more likely to be online, to make use of the Internet in a greater amount of time, to be more skilled and confident, characteristics that correspond perfectly to what digital narratives understand by digital natives. The sample consists of 595 children, which sums up 56\% boys and $44 \%$ girls, with an average age of $13(\mathrm{SD}=2.2)$. Highest education level of household ( 3 point scale, $1=$ primary or less education, $2=$ secondary education, $3=$ tertiary education) was used as a proxy for socioeconomic status. Here, education refers to the highest educational level of the parents in the household, and was chosen because it is a strong indicator of economic inequality and does not suffer from the non-response often encountered in questions regarding income. Furthermore, a dummy variable was created in order 
to measure the creative and most advanced step, based on the continuous variable that measures the number of online activities (Total=17), where creative use (more than 13 activities and at least one creative out of the last six from the ladder of opportunities) equals $1(\mathrm{~N}=71)$. It is worth to mention that we have labelled the dummy variable as creative based on the classification of activities counted in EUKO dataset made by Haserbrink et al. (2001). Most probably, we can name other activities as being creative and advanced. However, since we conducted our analysis on this dataset, we are forced to limit the understanding of this concept at the online activities included in the fifth step of the ladder of opportunities.

Drawing on the previous studies, six factors were introduced in the model out of which two are demographic variables (i.e. adolescent's gender, parent's education, online experience, time online, private use from own bedroom, digital skills and self-efficacy). Interaction terms among the variables were all entered in the second step, of which only those which contributed significantly were kept in the model. Child's age was not introduced in the model since it was considered a constant variable (as the sample consists only of 11-16 year olds). Table 2 presents the variables in the model. More details about measures and methods can be found at www.eukidsonline.net (see also Livingstone, Haddon and Görzig, 2012).

Table 2.

\section{Description of independent factors and dependent variable (creative Internet use)}

\begin{tabular}{|c|c|c|c|}
\hline Variable & Mean & Std. Dev. & Description \\
\hline $\begin{array}{l}\text { Child's gender } \\
(\text { Female }=0)\end{array}$ & .56 & & Dummy, Female $=0$ \\
\hline $\begin{array}{l}\text { Parent's education } \\
\text { (Highest in the } \\
\text { household. } \\
3 \text { point scale) }\end{array}$ & 2.14 & 0.40 & $\begin{array}{l}\text { Highest education level of household } \\
\text { (3 point scale, } 1=\text { primary or less } \\
\text { education, } 2=\text { secondary education, } \\
3=\text { tertiary education) }\end{array}$ \\
\hline Digital Skills & 4.49 & 2.59 & Scale variable, Total out of 8 \\
\hline Private use & 0.65 & 0.48 & $\begin{array}{l}\text { Dummy variable, own bedroom or other } \\
\text { private room at home (Yes }=1 \text { ) }\end{array}$ \\
\hline Online experience & 4.16 & 2.06 & $\begin{array}{l}\text { Number of years online, scale variable, } \\
\text { Highest }=12\end{array}$ \\
\hline Time online & 130.27 & 62.4 & $\begin{array}{l}\text { Minutes spent online everyday, scale } \\
\text { variable, Max }=270\end{array}$ \\
\hline Self-efficacy & 8.90 & 3.20 & $\begin{array}{l}\text { Range } 0-4 \text {, calculated from responses } \\
\text { 'true' at questions 'How true are these of } \\
\text { you?'(see Annex 4), scale variable }\end{array}$ \\
\hline $\begin{array}{l}\text { Creative use } \\
(>13 \text { activities }=1)\end{array}$ & .13 & & $\begin{array}{l}\text { Dummy variable, more than } 13 \text { activities } \\
\text { and at least one creative equals } 1(\mathrm{~N}=71)\end{array}$ \\
\hline
\end{tabular}

Source: EU Kids Online II dataset, author's computations. Valid N (listwise)= 595.

Base: All children, +11 year olds that use the Internet every day (Child's age Mean=13.62), in Romania. 


\section{Results}

The first analytical model is statistically significant and explains about $27 \%$ of the variation in the data, indicating a moderate relationship between predictors and dependent variable. However, we have to keep in mind that this $\mathrm{R}$ square is a pseudo R square, and it does not have the same significance as the $\mathrm{R}$ square in the linear regression. However, the value of Hosmer and Lemeshow goodness-of-fit (7.764) at a p value .457 indicates the model appears to fit the data reasonably well. Prediction success was overall $86.8 \%$. The second model, where the interaction terms were introduced, explains $35 \%$ of the variation according to the Nagelkerke R Square. As in the first model, Hosmer and Lemeshow goodness-of-fit (5.764) is significant at p. value .674, which also indicates reasonable fit to the data for the tested model. Both logistic regression models are represented in Table 3.

Table 3.

\section{Logistic regression predicting the odds of adolescents engaging in creative Internet uses}

\begin{tabular}{|c|c|c|c|c|c|c|}
\hline Variables in the Model(1)* & B & S.E. & Wald & df & Sig. & $\operatorname{Exp}(B)$ \\
\hline Child's Gender (Female- reference category) & .63 & .30 & 4.48 & 1 & .03 & 1.88 \\
\hline Parent's education (Tertiary- reference category) & .25 & 1.13 & 0.53 & 2 & .77 & 1.17 \\
\hline Primary or less education & .05 & 1.28 & 0.00 & 1 & .97 & 1.05 \\
\hline Secondary education & -.24 & .35 & 0.49 & 1 & .48 & .78 \\
\hline Online experience & .15 & .07 & 4.50 & 1 & .03 & 1.16 \\
\hline Time online & .01 & .00 & 10.00 & 1 & .00 & 1.01 \\
\hline Private use (Own bedroom- reference category) & .43 & .30 & 2.13 & 1 & .14 & 1.54 \\
\hline Self-efficacy & .20 & .35 & 0.33 & 1 & .56 & 1.22 \\
\hline Digital skills & .40 & .07 & 33.52 & 1 & .00 & 1.49 \\
\hline \multicolumn{7}{|l|}{ Variables in the Model (2) ${ }^{* *}$} \\
\hline Online experience & .47 & .28 & 2.81 & 1 & .09 & 1.60 \\
\hline Private use (Own bedroom- reference category) & 3.25 & 1.56 & 4.34 & 1 & .04 & .04 \\
\hline Child's Gender by Online experience & -.48 & .15 & 9.71 & 1 & .00 & .62 \\
\hline Private use by Digital skills & .44 & .16 & 7.00 & 1 & .01 & 1.55 \\
\hline \multicolumn{7}{|c|}{$\begin{array}{l}* \text { Chi-square=83.56, 8(df), Sig. =.00 (Omnibus Tests of Model Coefficients) } \\
-2 \text { Log likelihood=331.307; Cox and Snell R Square=.148; Nagelkerke R Square= } .270 \text {, } \\
86.8 \% \text { correctly classified cases. }\end{array}$} \\
\hline \multicolumn{7}{|c|}{$\begin{array}{l}\text { ** Chi-square }=113.815,26(\mathrm{df}), \text { Sig. }=.00 \text { (Omnibus Tests of Model Coefficients) } \\
-2 \text { Log likelihood=301.053; Cox and Snell R Square=.196; Nagelkerke R Square= } .357 \text {, } \\
\text { 88.5\% correctly classified cases. }\end{array}$} \\
\hline
\end{tabular}

Source: EU Kids Online dataset, author's computation.

Base: All children, 11+, in Romania. Internet frequency use: daily 
According to the first model, The Wald criterion has demonstrated that boys are 1.8 times more likely to engage in the last stage of Internet use than girls, when all other variables are held constant. Thus, boys, even when age is constant, are more likely to make use of the Internet in a more capital enhancing way, and consequently, in a more gainful way. These results are similar to previous studies. When tested for digital engagement, I have shown elsewhere (Fizesan [Balea], 2012) that boys are more experienced than girls, are involved in more online activities and make use of the internet from more locations. Also, when comparing boys and girls on overall 11-16 year-olds EUKO sample, the results show differences in breadth and nature of use based on gender. In average, boys are using the Internet for a longer time, are more skilled, and undertake a wider range of online activities than girls (Balea, 2012). Haserbrink et al. (2011) also showed in their cluster analysis that girls are less likely to be part of the focused social web-use cluster. According to their results, this cluster consists of most experienced and older users who spend more time online, get involved in the highest risk activities and are most likely to be boys. Moreover, these users are expected to benefit most from using the Internet since they engage in most creative and advanced activities. One of the reasons for these findings can be found if we take a look at the type of activities considered as advanced and creative (step 5 on the ladder of opportunities). We have to keep in mind that boys tend to get involved in more advanced activities when they play online games, for example, while girls incline to social networking activities that don't require high levels of digital skills.

The present findings emphasize that online experience is a powerful predictor since it significantly shapes the way adolescents make use of the Internet every day. According to the Wald criterion, for each year of experience gained, an adolescent has 1.16 more chances to achieve the final scale of the online activities' hierarchy. The same benefits are undertaken if they spend more time online. As the odds ratios shows, each minute spent online increases the chances to become an experienced user. Digital skills also help adolescents to benefit from their Internet use. For each digital skill gained, one is almost 1.49 more likely to belong to the group of digital natives, when all other variables are held constant. Private use is also a very strong and significant predictor. Using the Internet in a private setting increases the odds for a child to become creative user, when all other variables are held constant. Thus, adolescents who do not access the Internet from the privacy of their own bedroom are, in average, almost two times less likely to engage with the Internet in the most gainful way.

Highest education level of household, used as a proxy for socioeconomic status, does not hold for differences in the ways adolescents reach the final step of the ladder of opportunities, when they use the Internet every day. This result 
can be intriguing, but if we take a closer look at the characteristics of the sample we can understand why parent's education it is not a significant predictor for reaching the most advanced and creative step of Internet use. First, parent's education average is 2.14 ( 3 point scale, $3=$ tertiary education) meaning that most of the adolescents already come from a privileged background. Moreover, according to a previous work (Fizesan [Balea], 2012), parent's education does not hold for direct effects on children's digital engagement (measured as the total number of activities out 17) but holds for indirect effects. The analysis showed that children from higher educational background are more experienced, receive more support from their families and friends, and have more autonomy of use. Further, once a child makes use of the Internet on a daily basis, increases his digital skills and autonomy of use, thus parent's education becomes insignificant. Same analysis showed that older children use the Internet for longer and experience more autonomy of use, which makes them skilled, confident in their actions, and, are engaging in more activities, which explains why SES is not important when it comes to engaging in the most creative and advanced step.

According to the second model, when interaction terms are held constant, some variables lose their significance, while other become significant in shaping the chances for an adolescent to use the Internet in the most creative and advanced step. Online experience remains a significant predictor as in the first case, while gender and digital skills do not. Using the Internet from the privacy of their own bedroom increases the chances for an adolescent to become digital native, when all other variables are hold constant. Thus, for an adolescent who is not using the Internet in a private way there are fewer chances to become an experienced user. Furthermore, according to the Wald criterion, the second model emphasize that digital skills matter more for children with no private use from their own bedroom. Despite the fact that gender does not account for differences on its own in the chances for an adolescent to reach the final step, gender becomes significant when it interacts with online experience. Accordingly, girls need more years of experience in order to become digital natives compared with boys, when all other variables are constant. These results reinforce previous findings, as discussed at the first model.

\section{Conclusions}

This paper comes as a continuation and extension of earlier work (Fizesan [Balea], 2012) that argues that the way children make use of the Internet and the gratifications they gain after using it depend on the quality of access, the level of skills, the personal (e.g. Experience, self-efficacy, confidence) and positional 
resources (e.g. Age, gender, SES). Accordingly, older children are still more experienced, have Internet access from various locations and devices and exhibit higher levels of digital skills and self-efficacy resulting in a deep digital inclusion. As expected, children from better educated families use the Internet for a longer time, in various locations, develop more digital skills and self-efficacy and engage in more diverse activities. Furthermore, the same work indicates that even when adolescents are using the Internet with the same frequency, i.e. every day, the differences among them remain significant.

Based on this ground and arguing against "digital natives" narratives, the present study aimed to explore the way adolescents in Romania reach the most creative and advanced stage of Internet use. As figures showed, while most of the Romanian adolescents tend to settle for the most common and less gainful use of the Internet, there are some of them who make use of the most advanced and creative online activities. Therefore, the contribution of this paper relies on looking at those young people who engage in creative Internet uses, underlining predictors which push them over the boundaries of common use. Among digital skills, time online and online experience, gender is an important predictor for adolescent's online experience and for the benefits taken up online. Girls are less likely than boys to engage in a creative and gainful way. These findings are even more important since are focused on 11-16 years old who are online on daily basis. Girls need to work harder, to spend more time online in order to become an experienced user.

Unfortunately, the main discourse of digital native narratives often omits to consider these factors. They assume that children use online information effortlessly, due the fact that they have grown with it (Lorenzo et al., 2006; Green and Hannon, 2007; Kennedy et al., 2008). The present analysis argued against this homogenous view on this entire generation (i.e. Children and young adults) by emphasizing that generalizing the ways in which digital natives cope with these new technologies is a misconception since it fails to recognize the variations in adolescents' Internet usage. Moreover, this paper supports studies which suggest that the research of the relationship between children and new media should go beyond the basic dichotomy ubiquitous in digital natives' debate and should focus on developing a more comprehensive understanding of children's online behaviour (Bennet et al., 2008; Kennedy et al., 2009; Helsper and Enyon, 2009; Bennet and Maton, 2010). Drawing on this academic context, this research tested the dominance of the digital natives' agenda and turned its attention to the social context in which Internet usage occurs.

The limitations of this analysis touch different levels, some of them being more relevant for the purpose of this study. First, we measured the creative and advanced use using a dummy variable. Defining and measuring it can become 
a difficult exercise considering the amount of studies that suggest different ways to approach this concept. Some studies emphasize the importance of measuring it through observations and experiments of online children behaviour in real time. Another notable limitation is given by the type and number of online activities counted in the EUKO questionnaire. This list is not exhaustive and maybe is not the most appropriate for this type of analysis. But considering the fact that in Romania the research and literature on children's online behaviour are very scarce, these results can offer valuable insights about the way Romanian adolescents make use of the Internet. Lastly, the EUKO project has limitations that worth mentioning, and these should be kept in mind when interpreting and using the results. The main limitations refer at sampling procedures the recruitment process may not have reached the most vulnerable or marginalized children, survey context, the fact that it was conducted in homes with parents in the vicinity may have influenced the answers of some children, questionnaire, difficulty to hold children's attention for a longer time, national data, in some countries the national averages might mask quite diverse patterns within the country.

\section{REFERENCES}

Balea, B. (2012). From Unequal Access to Differentiate Use: Persistence of Digital Inequalities among Romanian Adolescents. $\mathrm{PhD}$ thesis.

https://www.academia.edu/3417151/From_Unequal_Access_to_Differentiate_ Use_Persistence_of_Digital_Inequalities_among_Romanian_Adolescents (Accessed 15.05.2016).

Balea, B., Barbovschi, M. (2013). Creative internet uses-differences in digital engagement among adolescents in Central and Eastern Europe (conference paper). IADIS International Conferencee-Society 2013, 13-16 March, 2013. Lisbon: Portugal.

Bennett, S. and Maton, K. (2010). Beyond the 'digital natives' debate: Towards a more nuanced understanding of students' technology experiences. Journal of Computer Assisted Learning, 26(5): 321-331.

Bennett, S., Maton, K. and Kervin, L. (2008). The 'digital natives' debate: A critical review of the evidence. British Journal of Educational Technology, 39(5): 775-786.

Barbovschi, M., and Fizesan [Balea], B. (2013). Closing the gap, are we there yet? Reflections on the persistence of second-level digital divide among adolescents in Central and Eastern Europe. In M. Ragnedda and G. Muschert (eds): The Digital Divide: The Internet and Social Inequality in International Perspective. London: Routledge.

DiMaggio, P., Hargittai, E., Celeste, C., and Shafer, S. (2004). Digital Inequality: From unequal access to differentiated use. New York: Sage.

Facer, K., Furlong, R. (2001). Beyond the myth of the 'cyberkid': Young people at the margins of the information revolution. Journal of Youth Studies, 4(4): 451-469. 
Fizesan [Balea], B. (2012). Digital engagement among children in Eastern Europe. Studia UBB Sociologia, 57(1): 83-101.

Green, H., and Hannon, C. (2007). Their Space: Education for a digital generation, online version, http://dera.ioe.ac.uk/23215/ (Accessed: 4.09.2011).

Hargittai, E. (2010). Digital Na(t)ives? Variation in Internet Skills and Uses among Members of the Net generation. Sociological Inquiry, 80 (1): 92-113.

Hasebrink, U., Görzig, A., Haddon, L., Kalmus, V. and Livingstone, S. (2011). Patterns of risk and safety online: in-depth analyses from the EU Kids Online survey of 9 to 16-year-olds and their parents in 25 European countries. London: EU Kids Online Network.

Helsper, E., Enyon, R. (2009). Digital natives: where is the evidence. British Educational Research, 36(3): 1-18. http://eprints.lse.ac.uk/27739/ (Accessed: 4.09.2011).

Jones, C. and Healing, G. (2010). Net Generation Students: Agency and Choice and the New Technologies. Journal of Computer Assisted Learning, 26(3): 344-356.

Kennedy, G., Dalgarno, B., Bennett, S., Judd, T., Gray, K. \& Chang, R. (2008). Immigrants and natives: Investigating differences between staff and students' use of technology. In Hello! Where are you in the landscape of educational technology? Proceedings ascilite Melbourne 2008.

http://www.ascilite.org.au/conferences/melbourne08/procs/kennedy.pdf (Accessed: 4.09.2011).

Kennedy, G., Judd, T., Dalgarnot, B. and Waycott, J. (2010). Beyond Digital Natives and Immigrants: Exploring Types of Net Generation Students. Journal of Computer Assisted Learning, 26 (5): 332-343.

Livingstone, S., Haddon, L., and Gorzig, A. (2012). Children, Risk and Safety Online: Research and policy challenges in comparative perspective. Bristol: The Policy Press.

Livingstone, S., Haddon, L., Görzig, A., and Ólafsson, K. (2011). Risks and safety on the Internet: The perspective of European children. Full findings. LSE, London: EU Kids Online.

Livingstone, S., and Helsper, E. (2010). Balancing opportunities and risks in teenagers' use of the Internet: The role of online skills and family context. New Media and Society, 12(2): 309-329.

Livingstone, S., and Helsper, E. (2007). Gradations in digital inclusion: Children, young people and the digital divide. New Media \&Society, 9: 671-696.

Lobe, B., Livingstone, S., Ólafsson, K., and Vodeb, H. (2011). Cross-national comparison of risks and safety on the Internet: Initial analysis from the EU Kids Online survey of European children. London: EU Kids Online, LSE.

Lorenzo, G., Oblinger, D. and Dziuban, C. (2006). How choice, co-creation, and culture are changing what it means to be net savvy. EDUCAUSE Quarterly, 30(1). http://connect.educause.edu/Library/EDUCAUSE+Quarterly/HowChoiceCo CreationandCul/40008. (Accessed 15.05.2016).

Prensky, M. (2001). Digital Natives, Digital Immigrants Part 1. On the Horizon, 9(5): 1-6.

Van Deursen, A.J.A.M. (2010). Internet skills. Vital assets in an information society. Enschede: Gildeprint Drukkerijen.

Van Dijk, J. (2005). The deepening divide. London: Sage.

Witte, J. and Mannon, S. (eds.) (2009). The Internet and Social Inequalities. New York: Routledge. 


\section{APPENDIX}

Table A1.

Variables used

\begin{tabular}{|c|c|c|c|}
\hline Digital Skills & $\%$ & & $\%$ \\
\hline $\begin{array}{l}\text { Compare different } \\
\text { websites to decide if } \\
\text { information is true }\end{array}$ & 58 & $\begin{array}{l}\text { Delete the record of which } \\
\text { sites you have visited }\end{array}$ & 58 \\
\hline Change filter preferences & 34 & $\begin{array}{l}\text { Change privacy settings } \\
\text { on a social networking } \\
\text { profile }\end{array}$ & 53 \\
\hline Bookmark a website & 53 & $\begin{array}{l}\text { Block messages from } \\
\text { someone you don't want } \\
\text { to hear from }\end{array}$ & 68 \\
\hline $\begin{array}{l}\text { Block unwanted adverts } \\
\text { or junk mail/spam }\end{array}$ & 47 & $\begin{array}{l}\text { Find information on how } \\
\text { to use the Internet safely }\end{array}$ & 69 \\
\hline \multicolumn{4}{|c|}{ Alpha $=.85$} \\
\hline $\begin{array}{l}\text { Self-efficacy (A bit true } \\
\text { and Very true) }\end{array}$ & $\%$ & & $\%$ \\
\hline $\begin{array}{l}\text { I am confident that I can } \\
\text { deal with unexpected } \\
\text { problems }\end{array}$ & 85 & $\begin{array}{l}\text { If I am in trouble I can } \\
\text { usually think of something } \\
\text { to do }\end{array}$ & 91 \\
\hline $\begin{array}{l}\text { It's easy for me to stick } \\
\text { to my aims and achieve } \\
\text { my goals }\end{array}$ & 89 & $\begin{array}{l}\text { I can generally work out } \\
\text { how to handle new } \\
\text { situations }\end{array}$ & 87 \\
\hline \multicolumn{4}{|c|}{ Alpha $=74$} \\
\hline $\begin{array}{l}\text { Digital engagement } \\
\text { (Activities online) }\end{array}$ & $\%$ & & $\%$ \\
\hline $\begin{array}{l}\text { Used the Internet for } \\
\text { school work }\end{array}$ & 85 & $\begin{array}{l}\text { Put (or posted) photos, } \\
\text { videos or music to share } \\
\text { with others }\end{array}$ & 37 \\
\hline $\begin{array}{l}\text { Played Internet games } \\
\text { on your own or against } \\
\text { the computer }\end{array}$ & 85 & Used a webcam & 52 \\
\hline Watched video clips & 85 & $\begin{array}{l}\text { Put (or posted) a message } \\
\text { on a website }\end{array}$ & 36 \\
\hline $\begin{array}{l}\text { Visited a social } \\
\text { networking profile }\end{array}$ & 62 & Visited a chat-room & 24 \\
\hline Used instant messaging & 92 & Used file sharing sites & 17 \\
\hline Sent/received email & 65 & $\begin{array}{l}\text { Created a character, pet or } \\
\text { avatar }\end{array}$ & 21 \\
\hline
\end{tabular}


BIANCA BALEA

\begin{tabular}{|l|c|l|l|c|}
\hline $\begin{array}{l}\text { Read/watched the news } \\
\text { on the Internet }\end{array}$ & 38 & $\begin{array}{l}\text { Spent time in a virtual } \\
\text { world }\end{array}$ & 12 \\
\cline { 1 - 3 } $\begin{array}{l}\text { Played games with other } \\
\text { people on the Internet }\end{array}$ & 61 & $\begin{array}{l}\text { Written a blog or online } \\
\text { diary }\end{array}$ & 12 \\
\cline { 4 - 5 } $\begin{array}{l}\text { Downloaded music or } \\
\text { films }\end{array}$ & 70 & & \multicolumn{2}{|c|}{ Alpha=.83 } \\
\hline \multicolumn{3}{|l|}{} \\
\hline
\end{tabular}

